\title{
Responses to Environmental Stress in Plants Adapted to Mediterranean Gypsum Habitats
}

\author{
Josep V. LLINARES ${ }^{1}$, Inmaculada BAUTISTA ${ }^{2}$, Maria del Pilar DONAT ${ }^{3}$, \\ Antonio LIDÓN ${ }^{2}$, Cristina LULL ${ }^{2}$, Olga MAYORAL ${ }^{3}$, Shantanu WANKHADE ${ }^{4}$, \\ Monica BOSCAIU ${ }^{5 *}$, Oscar VICENTE ${ }^{4}$ \\ ${ }^{1}$ Universitat Politècnica de València (UPV), EPS Gandía, Calle Paranimf 1, 46730 Gandia, Spain
${ }^{2}$ Universitat Politècnica de València (UPV), Re-Forest, Departamento de Ingeniería Hidráulica y Medio Ambiente, UPV, \\ Camino de Veras $/ n, 46022$ Valencia, Spain \\ ${ }^{3}$ Universitat Politècnica de València (UPV), Instituto de Investigación para la Gestión Integral de Zonas Costeras (IGIC, UPV), \\ Calle Paranimf 1, 46730 Gandia, Spain \\ ${ }^{4}$ Universitat Politècnica de València (UPV), Instituto de Biología Moleculary Celular de Plantas (IBMCP, UPV-CSIC), CPI, edificio 8E, \\ Camino de Veras $/ n, 46022$ Valencia, Spain \\ ${ }^{5}$ Universitat Politècnica de València (UPV), Instituto Agroforestal Mediterráneo (LAM, UPV), CPI, edificio 8E, Camino de Vera s/n, 46022 Valencia, Spain, \\ mobosnea@eaf.upv.es (*correspondingauthor)
}

\begin{abstract}
Gypsum areas are stressful environments inhabited by gypsophytes, plants that are exclusive for such habitats, and by plants that grow on gypsum but also on other soil types, the so-called gypsovags. To investigate possible differences between gypsovags and gypsophytes with respect to basic stress response mechanisms, two common osmolytes, glycine betaine and total soluble sugars, as well as monovalent $\left(\mathrm{Na}^{+}\right.$ and $\mathrm{K}^{+}$) and bivalent $\left(\mathrm{Ca}^{2+}\right.$ and $\left.\mathrm{Mg}^{2+}\right)$ cations, were quantified, under field conditions, in two Iberian endemic gypsophytes (Gypsophila struthium subsp. hispanica and Ononis tridentata) and two common Mediterranean gypsovags (Rosmarinus officinalis and Helianthemum syriacum). Their spatial variation according to a topographic gradient and their temporal variation over a period of three successive seasons were correlated with climatic data and soil characteristics. This analysis confirmed that water stress is the main environmental stress factor in gypsum habitats, whereas the percentage of gypsum in the soil does not seem to play any relevant role in the activation of stress responses in plants. Glycine betaine may contribute to stress tolerance in the gypsophytes, but not in the gypsovags, according to the close correlation found between the level of this osmolyte and the gypsophily of the investigated taxa. Cation contents in the plants did not correlate with those present in the soil, but the gypsophytes have higher levels of $\mathrm{Ca}^{2+}$ and $\mathrm{Mg}^{2+}$ than the gypsovags, under all environmental conditions, which may represent an adaptation mechanism to their specific habitat
\end{abstract}

Keywords: cations, gypsophytes, gypsovags, glycine betaine, total soluble sugars

\section{Introduction}

Soils with gypsum accumulation extend to over 100 million ha in the world, and are wide-spread in Africa and Asia (Verheye and Boyadgiev, 1997). In Europe, some of the largest deposits of gypsum are found in Spain (over 30000 $\mathrm{km}^{2}$ ), mostly in the dry South-Eastern part of the country (Mota et al., 2004). The vascular flora colonising these gypsum habitats is extremely diverse and includes many endemic and rare taxa. In the Iberian Peninsula alone, there are about 30 endemic gypsophyte species (Merlo et al., 1998) and Iberian gypsophile plant communities are considered as priority habitats, being among the most threatened in Europe (Gómez Campo, 1987; Pueyo et al., 2007). This high rate of endemicity is explained by the stressful environmental conditions affecting these habitats, which constitute a selective force for the evolution of endemics (Meyer, 1986). The environmental stress is caused by both physical and chemical constraints. Among the first, the limited water retention of the gypsum soils, combined with the arid climatic conditions present in gypsum zones, makes such habitat adverse for the establishment of flora, as it has been discussed by several authors (Martínez-Duro et al., 2010; Palacio et al., 2007; Pueyo et al., 2007). In addition, gypsum soils are characterised by mechanic instability and lack of plasticity and cohesion, structural deterioration and low porosity, which interfere with root growth (Verheye and Boyadgiev, 1997; Palacio et al., 2007). The formation of a hard soil surface crust restricts seedling establishment and limits the presence of many species in those areas (Escudero $e t$ al., 1997; Meyer, 1986; Meyer and García-Moya, 1989; Romao and Escudero, 2005). On the other hand, such soils 
have some chemical characteristics unsuitable for development of plants: deficiency of nutrients, ionic antagonisms and unbalanced ion concentration, with an excess of sulphur and calcium, and toxicity due to the high concentration of sulphate ions (Mota et al., 2004; Palacio et al., 2007).

The high rate of edaphic endemisms in anomalous habitats was explained by the 'refuge' (Gankin and Major, 1964) and the 'specialist' models (Meyer, 1986). Plants that fit to the refuge model are stress-tolerant, but show little competitiveness in the absence of stress. This model has been tested in several examples, such as serpentine endemics, which in experimental conditions developed better on normal soils in the absence of interspecific competition. In the specialist model, the endemic species is excluded from neighbouring areas, due to its adaptation to its own soil. Such specialist species always grow better in experimental conditions on their particular type of soils than on normal soils, even in the absence of competitors.

Plants that grow on gypsum soils are called gypsophytes when they are exclusive to such soils, and gypsovags when they appear on gypsum but also grow on other soil types. Palacio et al. (2007) considered that gypsovags are stress tolerant species that fit to the refugee model and grow on gypsum soils due to the reduced competition, whereas gypsophytes could be either specialists (in the case of regional dominant gypsophytes), but also refugees (as some narrow endemics).

Gypsicolous flora is of great scientific and conservationist interest, but responses to stress of plants from gypsum soils have not received much attention. Specifically, very little is known regarding one of the fundamental and conserved response mechanisms, based on the maintenance of cellular osmotic balance under stress conditions, through the control of ion transport and the biosynthesis and accumulation of different osmolytes in the cytoplasm. The mineral composition of plants present on gypsum habitats was analysed in early studies (Duvigneaud, 1968; Duvigneaud and Denaeyer-De Smet, 1966), while Alvarado et al. (2000) studied nitrogen metabolism in five species growing on gypsum. Palacio et al. $(2007,2014)$ reported differences in the chemical composition of ash, and in $\mathrm{Ca}, \mathrm{S}, \mathrm{N}, \mathrm{Mg} \mathrm{P}$ and $\mathrm{Na}$ concentrations between gypsophytes and gypsovags. However, the patterns of variation of stress markers - ions and osmolytes - according to spatial or temporal (seasonal) gradients in plants from gypsum areas have never been studied, except for our previous work describing environmentally-induced changes in proline contents in seven species from this habitat (Boscaiu et al., 2013).

The aim of the present work was to investigate possible differences in the responses of gypsophytes and gypsovags to abiotic stress, under field conditions in a natural gypsum zone. For this, we have analysed the accumulation of glycine betaine and soluble sugars - the most common osmolytes in plants besides proline, which was previously measured in the same plant material - as well as monovalent and bivalent cation contents, in two gypsophytes (Gypsophila struthium and Ononis tridentata) and two gypsovags (Rosmarinus officinalis and Helianthemum syriacum) sharing the same habitat; changes in the levels of these compounds were then correlated with differences regarding soil properties and meteorological data, in the selected experimental plots and in three successive seasons.

\section{Materials and methods}

\section{Selected taxa}

In the region of 'Los Serranos', where the gypsum study area is located, 1427 species of vascular plants have been described (Torres, 2007), of which only 37 live in the selected experimental plots. This is a very low figure, in agreement with the idea that gypsum represents a very stressful habitat for the establishment of flora. The area of study is characterised by the presence of two gypsum indicator plants: Ononis tridentata subsp. angustifolia (Lange.) Devesa López and Gypsophila struthium subsp. hispanica (Willk.) G. López, both included in the checklist of Iberian gypsophytes, ranking as ' 5 ' in the scale, which means species exclusive of gypsum soils. G. strutbium, an Iberian endemic of the family Caryophyllaceae, which appears on most of the Iberian gypsum outcrops, is considered as an excellent gypsum indicator (Martínez-Nieto, 2013). The subspecies G. struthium hispanica is restricted to the NorthEastern part of the Iberian Peninsula (López-Gonzalez, 1990). Ononis tridentata is a leguminous shrub of the western Mediterranean region, common in regions rich in gypsum and marl soils with dry climate. O. tridentata subsp. angustifolia is endemic to the Eastern Iberian Peninsula (Devesa, 2000). It grows on sunny and degraded slopes, related to the pathways of livestock.

The other two species are gypsovags, plants that often grow on gypsum soils, but are abundant also on different types of soils. Rosmarinus officinalis L. is a wide-spread Mediterranean labiates species frequent in dry areas, mostly on limestone. Helianthemum syriacum (Jacq.) Dum. Course (Cistaceae) is common throughout the Mediterranean region, on limestone, gypsiferous marls, dolomites and sandy soils.

\section{Study area and experimental design}

Samples were collected in summer (13 of July 2009), late autumn (11 of December 2009) and spring (26 of April 2010) near the village of Tuéjar, in the Province of Valencia (SE Spain) (39\%47'28”N, $\left.1^{\circ} 04^{\prime} 25^{\prime \prime W}\right)$ at 603 m.a.s.l. Three plots of $10 \times 10 \mathrm{~m}$ were selected on a hillside with a SW orientation and $11.5^{\circ}$ and $19^{\circ}$ slopes. Five individuals of each species were collected in the three plots, with exception of Gypsophila struthium that grew only in plot 3, which is the flattest and is situated at the bottom of the slope.

\section{Soil and climatic analysis}

For each sampling date, three random soil samples were taken from all experimental plots at a depth of $0-15 \mathrm{~cm}$. In the laboratory the samples were air-dried and passed through a $2 \mathrm{~mm}$ sieve and analysed to determine gypsum content, organic C, available P and assimilable K (Boscaiu et al. 2013). A 1:1 soil:water extract was prepared to determine electrical conductivity $\left(\mathrm{EC}_{1: 1}\right)$ and $\mathrm{pH}$.

Several multiple sensors (ECH2OT, Decagon ${ }^{\circledR}$ ) for salinity, humidity and temperature measurements were installed in April 2009, at depths of $10 \mathrm{~cm}$ and $20 \mathrm{~cm}$, and were connected to a datalogger (EM50, Decagon ${ }^{\circ}$ ) in each plot; additionally, sensors for air temperature and rainfall were also connected to the datalogger in plot 2. Climatic data 
for the month previous to the first sampling were obtained from the nearest agro-meteorological station, located in Chulilla.

\section{Plant material sampling}

Young shoots were sampled separately from five individuals of each taxon, cooled on ice and transported to the laboratory, where leaves were separated from branches. Part of the leaf material was frozen and stored at $-75^{\circ} \mathrm{C}$, while the rest was dried in the oven at $65^{\circ} \mathrm{C}$ for 3-4 days until constant weight, to obtain the percentage of dry weight (DW) of each individual. Biological samples were the same as those we used previously for the analysis of proline (Boscaiu et al., 2013).

\section{Osmolyte quantification}

For glycine betaine determination, frozen plant material (250 mg) was ground to a fine powder in a mortar, in the presence of liquid nitrogen. The extraction and quantification of glycine betaine was performed following the method of Grieve and Grattan (1983) with the modifications proposed by Nawaz and Ashraf (2010). For total soluble sugar (TSS) analyses, $50 \mathrm{mg}$ of fresh material was homogenised in $80 \%$ ethanol as described by Wankhade and Sanz (2013). TSS contents were estimated in aliquots of the extract by reaction with the anthrone- $\mathrm{H}_{2} \mathrm{SO}_{4}$ reagent, according to Fairbairn (1953), using glucose as standard.

\section{Cation contents}

Dry leaf material (300 mg) was digested in $8 \mathrm{ml}$ of $65 \%$ $\mathrm{HNO}_{3}$ and $2 \mathrm{ml}$ of $30 \% \mathrm{H}_{2} \mathrm{O}_{2}$ in a microwave digestor (Model Ethos One) as described by Grigore et al. (2012). The quantification of $\mathrm{Na}^{+}$and $\mathrm{K}^{+}$was performed by flame spectrometry, in a Jenway PFP 7 spectrophotometer, and atomic absorption spectrometry (in a Varian SpectrAA 220) was used for $\mathrm{Ca}^{2+}$ (at $239.9 \mathrm{~nm}$ ) and for $\mathrm{Mg}^{2+}$ (at $202.6 \mathrm{~nm}$ ) determinations.

\section{Statistical analysis}

Data were analysed by the StatGraphic Centurion 16 and SPSS v.15 programmes. Significance of seasonal differences for soil and plant parameters in each plot were analysed by one-way ANOVA. Prior to ANOVA, the normality and homogeneity of variance were checked. When the ANOVA null hypothesis was rejected, post-hoc comparisons were performed using the Tukey test. A two-way ANOVA was applied to test the effect of season and plot on the osmolyte and cation contents in plants. Ecological factors were correlated with variations in osmolyte and ion contents of the four studied species by the multivariate approach of principal component analysis (PCA).

\section{Results and discussions}

General soil properties were characterized at the beginning of the study and were reported in a previous publication (Boscaiu et al., 2013). The soil in the studied area is gypsiferous, but gypsum content varied among plots. The two upper plots (1 and 2) had significantly lower values of gypsum content than the lower plot 3 (Table 1). A high gypsum content means less available $\mathrm{K}$, organic $\mathrm{C}$ and water holding capacity showing that such habitats have low soil fertility and water retention capacity.
The climate is typical Mediterranean, with hot and dry summers. The higher reference evapotranspiration in correlation with the absence of rainfall during almost the entire summer resulted in a pronounced water deficit prior to the first sampling, in the summer of 2009 . On the contrary, due to abundant rainfall the next spring, there was practically no water deficit in the month previous to this sampling (Fig. 1). Seasonal variability of climate may influence many soil properties. Indeed, several soil parameters showed not only spatial differences among plots, but also a seasonal variation within the same plot. Due to the topographic position of the plots, soil humidity throughout the studied period was higher in plot 3, situated at the bottom of the slope, whereas plots 1 and 2 were much drier. In summer, the sensors located in the three plots detected significantly lower soil humidity in relation to the dryness of the climate (data not shown).

Soil salinity determined as $\mathrm{EC}_{1: 1}$ (in 1 to 1 soil-water extracts) was moderate, steady in time and similar in the three plots. The variation in soil $\mathrm{pH}$ and available $\mathrm{K}$ could not be

Table 1. Soil properties (mean values \pm standard deviation, $n=9$ ) of the three plots under study; values followed by the same letter do not significantly differ at probability level less than 5\%. EC 1:1: electric conductivity in 1-to-1 soilwater extracts; WHC: water holding capacity; OC: organic carbon

\begin{tabular}{cccc}
\hline Characteristic & Plot 1 & Plot 2 & Plot3 \\
\hline Gypsum $(\%)$ & $33.50 \pm 15.40 \mathrm{a}$ & $49.80 \pm 14.60 \mathrm{a}$ & $74.10 \pm 23.00 \mathrm{~b}$ \\
EC $_{1: 1}\left(\mathrm{dS} \mathrm{m}^{-1}\right)$ & $2.52 \pm 0.21 \mathrm{a}$ & $2.40 \pm 0.14 \mathrm{a}$ & $2.40 \pm 0.15^{\mathrm{a}}$ \\
pH & $7.93 \pm 0.05 \mathrm{a}$ & $7.87 \pm 0.06 \mathrm{a}$ & $7.90 \pm 0.10^{\mathrm{a}}$ \\
WHC $(\%)$ & $21.60 \pm 5.30 \mathrm{ab}$ & $23.40 \pm 3.70 \mathrm{~b}$ & $18.10 \pm 5.50 \mathrm{a}$ \\
OC $(\%)$ & $1.49 \pm 0.72 \mathrm{~b}$ & $1.38 \pm 0.89 \mathrm{ab}$ & $0.76 \pm 0.51 \mathrm{a}$ \\
PBurriel $\left(\mathrm{mgkg}^{-1}\right)$ & $1.26 \pm 0.35 \mathrm{a}$ & $1.39 \pm 0.36 \mathrm{a}$ & $2.20 \pm 0.66 \mathrm{~b}$ \\
AvailableK $\left(\mathrm{mgkg}^{-1}\right)$ & $229.00 \pm 87.20 \mathrm{~b}$ & $164.20 \pm 80.70 \mathrm{ab}$ & $132.00 \pm 82.30 \mathrm{a}$ \\
\hline
\end{tabular}

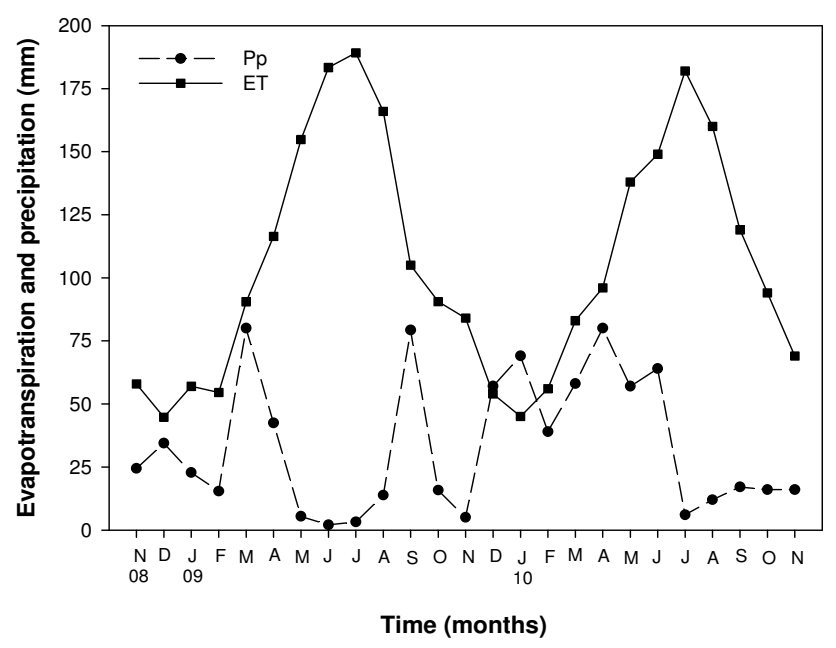

Fig. 1. Water deficit represented in function of monthly precipitation and evapotranspiration data registered by the nearest meteorological station, located in Chulilla

related to a seasonal pattern, but the latter was lower in plot 3, which has the highest amount of gypsum (Table 1).

As mentioned above, Mediterranean climate is characterized by a peak of water deficit in summer, which is restrictive for plants. Therefore, contrary to plants in milder temperate climates, which suffer the rigor of winter, Mediterranean plants endure the most stressful conditions in 
summer. In conditions of drought most plants lose water from their tissues. The percentages of dry weight detected in leaves were generally higher in summer (Fig. 2), except in $O$. tridentata, which has succulent leaves; thus, changes in water content do not necessarily follow a seasonal pattern. Anatomic studies by Grigore et al. (2011) showed that $O$. tridentata leaves do not have typical aquiferous tissue, but long palisade cells, occupying almost all leaf lamina, which confers succulence.

A basic general response to drought is the synthesis and cytoplasmic accumulation of osmolytes, a conserved phenomenon observed in all plants, tolerant as well as sensitive to stress (Munns and Tester, 2008). Osmolytes are compatible solutes, diverse low-molecular-weight organic compounds that do not interfere with normal metabolism even when present at high concentrations. Their primary function in plants is to prevent water loss, maintaining cell turgor and thus the gradient for water uptake into the cell.

Proline (Pro) and glycine betaine (GB) are two of the most common plant osmolytes, synthesised in response to different abiotic stresses that cause cellular dehydration (Ashraf and Foolad, 2007; Chen and Murata, 2008; Verbruggen and Hermans, 2008). Besides their primary role

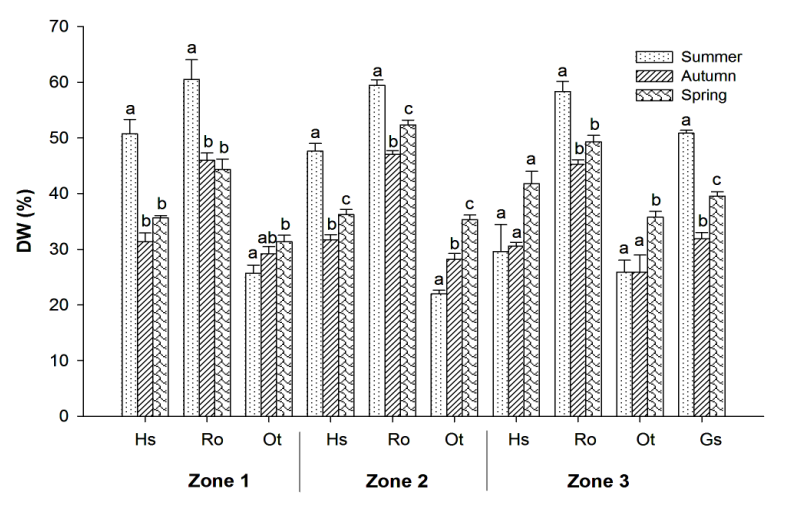

Fig. 2. Dry weight percentages (with respect to fresh weight) of the investigated taxa, in the three plots under study in summer 2009, autumn 2009 and spring 2010. Different letters indicate seasonal significant differences within each species and plot. Species abbreviations: Ro, Rosmarinus officinalis; Hs, Helianthemum syriacum; Ot, Ononis tridentata; Gs, Gypsophila strutbium

small spatial and seasonal variation of this compound in the four species (Tables 2 and 3, Fig. 3), which was generally not significant or did not correlate with soil water availability or other environmental factors that could affect the synthesis of osmolytes. Similar results, regarding the absence of significant variations of GB levels in response to strong seasonal fluctuations in the degree of environmental stress, have been previously reported in GB accumulators from other habitats (Gil et al., 2014). Therefore, it is not clear whether this osmolyte plays a relevant role in the stress tolerance mechanisms of the studied species but, in any case, its contribution to osmotic adjustment should be more important in $O$. tridentata than in the other taxa.

Soluble carbohydrates, such as sugars (e.g. sucrose, glucose, in osmotic adjustment, Pro and GB have other functions in plants, such as scavenging free oxygen radicals and stabilizing cellular membrane structures. They also play a role in the regulation of gene expression as signalling molecules, and serve as metabolites for the cellular storage of carbon and nitrogen during stress, which would be used by the cell once stress has ceased (Munns and Tester, 2008; Szabados and Savouré, 2010). We reported variation in Pro contents in the four species under study, in a previous publication (Boscaiu $e t$ al., 2013). Pro levels were found to closely correlate with climate parameters in the gyspovags $H$. syriacum and $R$. officinalis, but not in the gyspohytes $G$. struthium and $O$. tridentate.

In the present work, we have detected low GB contents in all taxa except $O$. tridentata, which contains double concentration of this osmolyte, in comparison with the other species (Fig. 3). Yet these levels are still lower than the values measured in halophytes that are typical GB accumulators (Khan et al., 2000; Tipirdamaz et al., 2006). There was only a

Table 2. Significant effect of spatial (plot) and seasonal variations of plant osmolytes and cations for the three species present in the three plots at $99.99 \%\left({ }^{*}\right)$, at $99 \%\left({ }^{* *}\right)$ and $95 \%\left({ }^{*}\right)$ confidence levels, according to two-way ANOVA. NS: not significant. Species abbreviations as in Fig. 1

\begin{tabular}{|c|c|c|c|c|}
\hline Property & Species & Plot & Season & Interaction \\
\hline \multirow{3}{*}{ DW } & Ro & NS & *** & NS \\
\hline & $\mathrm{Hs}$ & * & *** & $* * *$ \\
\hline & $\mathrm{Ot}$ & NS & *** & $*$ \\
\hline \multirow{3}{*}{ Proline } & Ro & NS & *** & NS \\
\hline & $\mathrm{Hs}$ & $* *$ & $* * *$ & $* * *$ \\
\hline & $\mathrm{Ot}$ & NS & $* * *$ & NS \\
\hline \multirow{3}{*}{$\begin{array}{l}\text { Glicyne } \\
\text { betaine }\end{array}$} & Ro & ** & *** & NS \\
\hline & Hs & NS & $*$ & $*$ \\
\hline & $\mathrm{Ot}$ & NS & $* * *$ & NS \\
\hline \multirow{3}{*}{ TSS } & Ro & NS & *** & NS \\
\hline & Hs & NS & $* * *$ & $* *$ \\
\hline & $\mathrm{Ot}$ & $* * *$ & $* * *$ & $* * *$ \\
\hline \multirow{3}{*}{$\mathrm{Na}$} & Ro & ** & *** & *** \\
\hline & $\mathrm{Hs}$ & NS & *** & $*$ \\
\hline & $\mathrm{Ot}$ & $* * *$ & $*$ & NS \\
\hline \multirow{3}{*}{$\mathrm{K}$} & Ro & $* * *$ & *** & $* *$ \\
\hline & $\mathrm{Hs}$ & $* * *$ & *** & *** \\
\hline & Ot & $* * *$ & *** & NS \\
\hline \multirow{3}{*}{$\mathrm{Ca}$} & Ro & $* * *$ & *** & $* * *$ \\
\hline & $\mathrm{Hs}$ & $*$ & *** & $*$ \\
\hline & $\mathrm{Ot}$ & * & *** & $*$ \\
\hline \multirow{3}{*}{$\mathrm{Mg}$ ? } & Ro & $* * *$ & $* * *$ & $* * *$ \\
\hline & $\mathrm{Hs}$ & NS & *** & * \\
\hline & $\mathrm{Ot}$ & NS & $* * *$ & NS \\
\hline
\end{tabular}

Table 3. Significant effect of seasonal variations on osmolytes and cations in G. struthium present only in plot 3, according to one-way ANOVA

\begin{tabular}{cc}
\hline Property & Season \\
\hline DW & ${ }^{* *}$ \\
Proline & ${ }^{*}$ \\
GB & NS \\
TSS & $* * *$ \\
$\mathrm{Na}$ & ${ }^{*}$ \\
$\mathrm{~K}$ & ${ }^{* *}$ \\
$\mathrm{Ca}$ & $* * *$ \\
$\mathrm{Mg}$ & $* *$ \\
\hline
\end{tabular}


41

fructose or trehalose) or polyalcoholss (sorbitol, mannitol, different inositol derivates, etc.) also play a role as functional osmolytes in several species; however, their participation in specific stress tolerance mechanisms are often difficult to assess, due to their multiple additional functions as primary energy sources, metabolic precursors and regulatory signalling molecules (Gil et al., 2013). Total soluble sugars (TSS) have been reported by many authors to increase under salt stress (Gil et al., 2013, and references therein) and drought (Rodrigues et al., 2010; Souza et al., 2004) conditions; yet many other reports indicated the opposite: a stress-dependent reduction of TSS contents (Alves and Setter, 2004). In the four species analysed here, TSS levels were similar in the three plots, but a seasonal pattern of variation was observed, with higher TSS concentrations in autumn (Tables 2 and 3, Fig. 4). Since TSS levels did not correlate with environmental stress factors, this increase is probably related to phenological changes in the plants, and do not support a role for TSS in osmotic adjustment or, in general, stress tolerance.

Salinity and drought also affect plant mineral nutrition and disrupt ion homeostasis. An increase of $\mathrm{Na}^{+}$ concentration in plants has been generally observed under saline stress, but obviously not in plants affected by water stress. The levels of $\mathrm{Na}^{+}$registered in the four selected species were extremely low (Fig. 5), not at all comparable to those reported in halophytes, or plants adapted to saline environments (Gil et al., 2014); this was to be expected since salt stress in gypsum soils is not due to sodium salts, the most abundant in most soil types, but to calcium sulphate. Potassium, on the other hand, is an essential element in plant nutrition and it is involved in many metabolic processes. A decrease of $\mathrm{K}^{+}$levels in water-stressed plants has been observed in many species, mainly due to membrane damage and disruption in ion homeostasis (Wang et al., 2013); yet $\mathrm{K}^{+}$ has also been reported to increase under drought conditions, contributing significantly, as the 'physiological' cation, to cellular osmotic adjustment (Silva et al., 2010). In the four species included in the present study, and in the three experimental plots, a significant increase in $\mathrm{K}^{+}$levels was registered in autumn, coinciding with increased
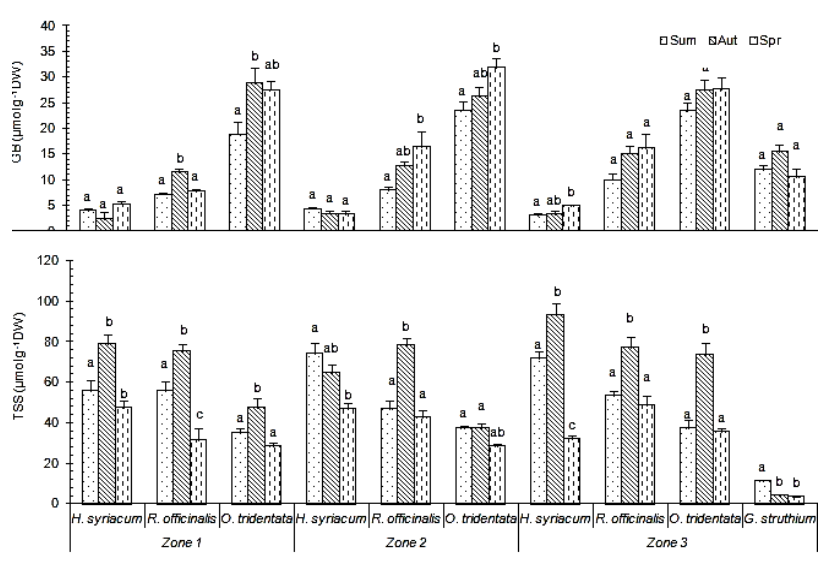

Fig. 3. Variation of glycine betaine (GB) and total soluble sugars (TSS) contents in the investigated taxa, in the three plots under study in summer 2009, autumn 2009 and spring 2010. Different letters indicate seasonal significant differences within each species and plot

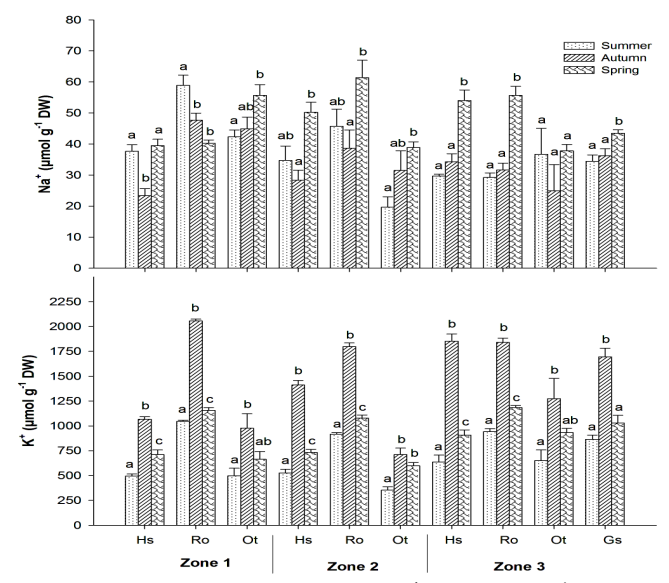

Fig. 4. Variation of monovalent cation $\left(\mathrm{Na}^{+}\right.$and $\left.\mathrm{K}^{+}\right)$contents in the investigated taxa, in the three plots under study in summer 2009, autumn 2009 and spring 2010. Different letters indicate seasonal significant differences within each species and plot. Species abbreviations as in Fig. 1

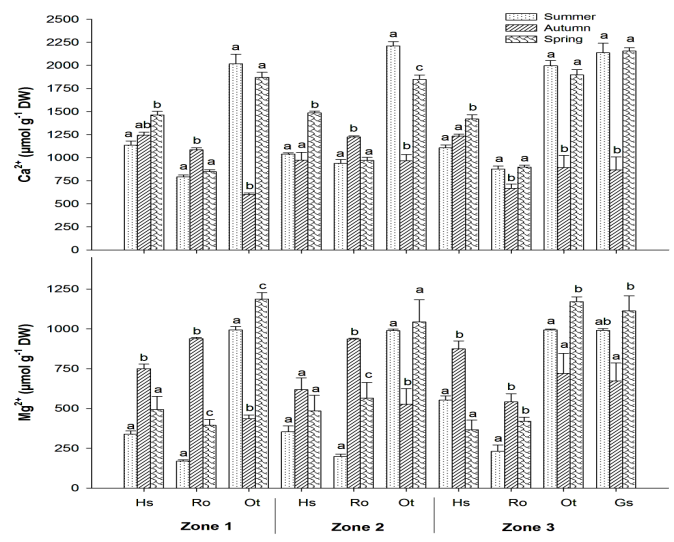

Fig. 5. Variation of bivalent cation $\left(\mathrm{Ca}^{2+}\right.$ and $\left.\mathrm{Mg}^{2+}\right)$ contents in the investigated taxa, in the three plots under study in summer 2009, autumn 2009 and spring 2010. Different letters indicate seasonal significant differences within each species and plot. Species abbreviations as in Fig. 1

Plot of Component Weights

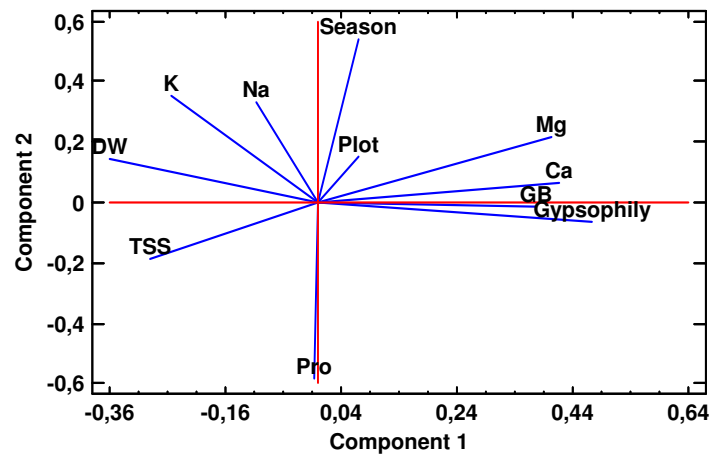

Fig. 6. Biplot from the principal component analysis (PCA) showing the relationships among proline (Pro), glycine betaine (GB), total soluble sugars (TSS), $\mathrm{Na}, \mathrm{K}, \mathrm{Ca}$ and $\mathrm{Mg}$ in plants, and environmental factors summarised as the 'plot' and 'season' variables. Gyspophily is a variable introduced to indicate whether the species are gyspophytes or gyspovags 
concentration of total sugars (Fig. 4). This pattern may be correlated with an intensification of metabolic processes after the more stressful summer period or with phenological stages of the plants, but apparently not with stress tolerance.

Another essential mineral nutrient is the divalent cation $\mathrm{Ca}^{2+}$, involved in a wide array of cellular processes, such as cell wall stabilisation, maintenance of cell membrane integrity and control of membrane permeability and selectivity, cationanion balance and osmoregulation (Marschner, 1995). $\mathrm{Mg}^{2+}$, the other major divalent cation, also plays an important structural and functional role in plants. It is part of the ring structure of the chlorophyll molecule and is a cofactor of many enzymes involved in respiration and photosynthesis, or in the synthesis of DNA and RNA (Marschner, 1995). The concentration of $\mathrm{Ca}^{2+}$ may fluctuate according to the type and intensity of stress, but also with the species or even the tissue type within a species (Kader and Lindberg, 2010). Similarly, $\mathrm{Mg}^{2+}$ contents largely vary in plants in response to stress but, here again, many reports indicate an increase (Joshi 1984), while others showed a decrease (Loupassaki et al., 2002) in its levels. In the analysed taxa, there was no clear pattern of variation in the bivalent cation levels (Fig. 5) and no correlation with soil characteristics (Table 1).

A 'principal component analysis' (PCA) was performed in order to establish possible correlations of changes in osmolytes and cation contents in the plants and environmental variables (Fig. 6). Proline levels in the plant samples, determined previously (Boscaiu et al., 2013) were also included in the analysis. Considering climatic data (the previous month rainfall and mean air temperature) and soil properties (soil moisture at $10 \mathrm{~cm}$ depth, electric conductivity and gypsum content), environmental variables were defined as 'season' and 'plot' and assigned arbitrary values according to the degree of abiotic stress affecting the plants in each season, and to the gypsum content in each plot, respectively. Thus, spring was assigned a value of ' 1 ', as the less stressful season, followed by autumn (' 2 ') and summer (' 3 '); similarly, plots 1 , 2 and 3 , were assigned ' 1 ', ' 2 ' and ' 3 ' values, respectively, according to an increasing level of gypsum in the soil. An additional variable was included in the PCA, grouping the investigated taxa according to their degree of gyspophily, with a lower value (' 1 ') assigned to gyspsovags and a higher one ('2') associated with gypsophytes. About $74 \%$ of the variance was explained by the cumulative percentage of three components, with Eigenvalues greater than 1. The first component (X-axis in Fig. 6), which explained 32.5\% of variance, was defined by the character of gypsophily of the plants, showing a strong positive correlation with $\mathrm{GB}, \mathrm{Ca}^{2+}$ and $\mathrm{Mg}^{2+}$ contents and a negative correlation with the percentage of dry weight, TSS and K contents. The second component (Y-axis), which explained a further $16 \%$ of the variance, was closely associated to the variable 'season' - that is, mostly with the degree of water stress, since water deficit is maximum in summer (3) and minimum in spring (1) - and, to a lesser extent, with the variable 'plot': due to its topographic position at the bottom of the hill, plot 3 contained the highest gypsum level and was the most humid throughout the year (value 3). This component was negatively correlated only with the amount of proline, but not with other osmolytes or cations.

The PCA highlighted the statistically significant correlation of $\mathrm{Ca}^{2+}$ and $\mathrm{Mg}^{2+}$ levels with the gypsophilous character of the plants, while cation contents were not associated to environmental parameters. These data are in agreement with the absolute values measured in the four species. Mean $\mathrm{Ca}^{2+}$ concentrations of 1588 and $1719 \mu \mathrm{mol} \mathrm{g}$ DW were determined in O. tridentata and in G. struthium, respectively, which were higher than in the two gypsovags (1 $236 \mu \mathrm{molg}^{-1} \mathrm{DW}$ in $H$. syriacum and $922 \mu \mathrm{molg}^{-1} \mathrm{DW}$ in $R$. officinalis). The same was found for $\mathrm{Mg}^{2+}$, significantly higher in the gypsophytes $\left(895 \mu \mathrm{molg}^{-1} \mathrm{DW}\right.$ in 0 . tridentata and 925 $\mu \mathrm{molg}{ }^{-1} \mathrm{DW}$ in G. struthium) than in the gypsovags (538 and $419 \mu \mathrm{molg}^{-1} \mathrm{DW}$ in $H$. syriacum and $R$. officinalis, respectively). Palacio et al. (2014) have also reported recently higher levels of $\mathrm{Ca}$ and $\mathrm{Mg}$ in G. struthium and O. tridentata than in gypsovag taxa. The higher water content - succulence - observed in many gypsophiles may have a diluting effect on toxic sulphate levels in the cell, as discussed by Parsons et al. (1976), in addition to being an adaptation to dry habitats.

\section{Conclusions}

The present work confirms that water stress is the main environmental stress factor in gypsum habitats, whereas the percentage of gypsum in the soil does not seem to play any relevant role in the activation of stress responses in the plants. Proline accumulation appears to be an excellent indicator of stress in many species, including the two gypsovags analysed in the present work, but not in the two gypsophytes. Glycine betaine, on the contrary, may contribute to the stress tolerance mechanisms in the latter taxa or, at least, in $O$. tridentata, which accumulated this osmolyte to higher levels than the other species. Cation contents in the plants did not correlate with those present in the soil, but the current study indicates that the gypsophytes have higher levels of $\mathrm{Ca}^{2+}$ and $\mathrm{Mg}^{2+}$ than the gypsovags, under all environmental conditions, which may represent an adaptation mechanism to their specific habitat.

\section{Acknowledgements}

This work has been supported by the Spanish Ministry of Science and Innovation (Project CGL2008-00438/BOS), with contribution from the European Regional Development Fund.

\section{References}

Alvarado JJ, Ruiz JM, López-Cantarero I, Molero J, Romero L (2000). Nitrogen Metabolism in five plant species characteristic of gypsiferous soils. Plant Physiol 156:612-616.

Alves AAC, Setter TL (2004). Abscisic acid accumulation and osmotic adjustment in cassava under water deficit. Environ Exp Bot 51:259-271.

Ashraf MY, Foolad MR (2007). Roles of glycine betaine and proline in improving plant abiotic stress resistance. Environ Exp Bot 59:206-216.

Boscaiu M, Bautista I, Lidón A, Llinares J, Lull C, Donat P, Mayoral O, Vicente O (2013). Environmental-dependent proline accumulation in plants living on gypsum soils. Acta Physiol Plant 35:2193-2204. 
43

Chen THH, Murata N (2008). Glycinebetaine: an effective protectant against abiotic stress in plants. Trends Plant Sci 13:499-505.

Devesa JA (2000). Ononis L., p. 590-646. In: Talavera S, Aedo C, Castroviejo S, Herrero A, Romero Zarco C, Salgueiro FJ, Velayos M (Eds.). Flora iberica, vol. 7 (2), Leguminosae (partim). Servicio de Publicaciones del CSIC, Madrid.

Duvigneaud P (1968). Essai de classification chimique (éléments minéraux) des plantes gypsicoles du bassin de l'Ebre. B Soc Roy Bot 101:279-291.

Duvigneaud P, Denaeyer-De Smet S (1966). Accumulation du soufre dans quelques espèces gypsophiles d'Espagne. B Soc Roy Bot 99:263-269.

Escudero A, Carnes L, Pérez García F (1997). Germination of gyspohytes and gypsovags in semiarid central Spain. J Arid Environ 36:487-497.

Fairbairn NJ (1953). A modified anthrone reagent. Chem Ind 4:86.

Gankin R, Major J (1964). Arctostaphylos myrtifolia, its biology and relationship to the problem of endemism. Ecology 45:792-808.

Gavaghan CL, Li JV, Hadfield ST, Hole S, Nicholson JK, Wilson ID, Howe PWA, Stanley PD, Holmes E (2011). Application of NMR-based metabolomics to the investigation of salt stress in maize (Zea mays). Phytochem Analysis 22:214-224.

Gil R, Bautista I, Boscaiu M, Lidón A, Wankhade S, Sánchez H, Llinares J, Vicente O (2014). Responses of five Mediterranean halophytes to seasonal changes in environmental conditions. AoB PLANTS 6: plu049; doi:10.1093/aobpla/plu049.

Gil R, Boscaiu M, Lull C, Bautista I, Lidón A, Vicente O (2013). Are soluble carbohydrates ecologically relevant for salt tolerance in halophytes? Funct Plant Biol 40:805-818.

Gómez-Campo C (1987). Libro rojo de especies vegetales amenazadas de España peninsular e Islas Baleares. ICONA, Ministerio de Agricultura, Pesca y Alimentación, Madrid.

Grieve CM, Grattan SR (1983). Rapid assay for determination of water soluble quaternary ammonium compounds. Plant Soil 70:303-307.

Grigore MN, Boscaiu M, Llinares J, Vicente O (2012). Mitigation of salt stress-induced inhibition of Plantago crassifolia reproductive development by supplemental calcium or magnesium. Not Bot Horti Agrobo Cluj-Napoca 40:58-66.

Grigore MN, Toma C, Zamfirache MM, Boscaiu M (2011). Anatomical condiderations on Spanish gyspohytes. Where is their place within plant ecology? An Stiint Univ Al I Cuza Iasi Sect II Biol Veg 57:31-38.

Joshi SS (1984). Effect of salinity stress on organic and mineral constituents in the leaves of pigeonpea (Cajanus cajan L. var. C11). Plant Soil 82:69-76.

Kader MA, Lindber S (2010). Cytosolic calcium and pH signaling in plants under salinity stress. Plant Signal Behav 5:223-228.

Khan MA, Ungar IA, Showalter AM (2000). The effect of the salinity on the growth, water status, and ion content of a leaf succulent perennial halophyte, Suaeda fruticosa (L.) Forssk. J Arid Environ 45:73-84.

López González G (1990). Gypsohila L. In: Castroviejo S et al.
(Eds.), Flora Iberica 2, p. 408-415. Real Jardín Botánico, CSIC, Madrid.

Loupassaki MH, Chartzoulakis KS, Digalaki NB, Androulakis II (2002). Effects of salt stress on concentration of nitrogen, phosphorus, potassium, calcium, magnesium and sodium in leaves, shoots, and roots of six olive cultivars. J Plant Nutr 25:2457-2482.

Marschner $H$ (1995). Mineral nutrition of higher plants, 2nd Ed. Academic Press, London.

Martínez Nieto M, Seggara-Moragues JG, Merlo E, MartínezHernández F, Mota JF (2013). Genetic diversity, genetic structure and phylogeography of the Iberian endemic Gypsophila struthium (Caryophyllaceae) as revealed by AFLP and plastid DNA sequences: connecting habitat fragmentation and diversification. Bot J Lin Soc 173:654-675.

Martínez-Duro E, Ferrandis P, Escudero A, Luzuriaga AL, Herranz JM (2010). Secondary old-field succession in an ecosystem with restrictive soils: does time from abandonment matter? Appl Veg Sci 13:234-248.

Merlo ME, Mota JF, Cabello J, Alemán MM (1998). La gipsofilia en plantas: un apasionante edafismo. Investigación y Gestión 3:103-112.

Meyer SE (1986). The ecology of gypsophyle endemism in the eastern Mojave desert. Ecology 67:1303-1313.

Meyer SE, García-Moya E (1989). Plant community patterns and soil moisture regime in gypsum grasslands of north central Mexico. J Arid Environ 16:147-155.

Mota JF, Sánchez Gómez P, Merlo Calvente ME, Catalán Rodríguez P, Laguna Lumbreras E, de la Cruz Rot M, Navarro Reyes FB, Marcha Gallardo F, Bartolomé Esteban C, Martínez Labarga JM, et al. (2009). Aproximación a la checklist de los gipsófitos ibéricos. Anales de Biología 31:21-80.

Mota JF, Sola AJ, Jiménez-Sánchez ML, Pérez-García F, Merlo ME (2004). Gypsicolous flora, conservation and restoration of quarries in the southeast of the Iberian Peninsula. Biodivers Conserv 13:1797-1808.

Munns R, Tester M (2008). Mechanisms of salinity tolerance. Ann Rev Plant Biol 59:651-681.

Nawaz K, Ashraf M (2010). Exogenous application of glycinebetaine modulates activities of antioxidants in maize plants subjected to salt stress. J Agron Crop Sci 196:28-37.

Palacio S, Aitkenhead M, Escudero A, Montserrat-Martí G, Maestro M, Robertson AH (2014). Gypsophile chemistry unveiled: Fourier transform infrared (FTIR) spectroscopy provides new insight into plant adaptations to gypsum soils. PLoS One. doi: 0.1371/journal.pone.0107285.

Palacio S, Escudero A, Montserrat-Martí G, Maestro M, Milla R, Albert M (2007). Plants living on gypsum: beyond the specialist model. Ann Bot 99:333-343.

Parida A, Das AB, Das P (2002). NaCl stress causes changes in photosynthetic pigments, proteins and other metabolic components in the leaves of a true mangrove, Bruguiera parviflora, in hydroponic cultures. J Plant Biol 45:28-36.

Parsons RF (1976). Gypsophily in plants. A review. Am Midl Nat 96:1-20. 
Pueyo Y, Alados CL, Maestro M, Komac B (2007). Gypsophile vegetation patterns under a range of soil properties induced by topographical position. Plant Ecol 189:301-311.

Rodrigues BM, Souza BD, Nogueira RM, Santos MG (2010). Tolerance to water deficit in young trees of jackfruit and sugar apple. Rev Cienc Agron 41:245-252.

Romao RL, Escudero A (2005). Gypsum physical soil crusts and the existence of gypsophytes in semi-arid central Spain. Plant Ecol 181:127-137.

Silva EN, Ferreira-Silva SL, Viégas RA, Silveira JAG (2010). The role of organic and inorganic solutes in the osmotic adjustment of drought-stressed Jatropha curcas plants. Environ Exp Bot 69:279-285.

Souza RP, Machado EC, Silva JAB, Lagôa AMMA, Silveira JAG (2004). Photosynthetic gas exchange, chlorophyll fluorescence and some associated metabolic changes in cowpea (Vigna unguiculata) during water stress and recovery. Environ Exp Bot 51:45-56.

Szabados L, Savouré A (2010). Proline: a multifunctional amino acid. Trends Plant Sci 15:89-97.
Tipirdamaz R, Gagneul D, Duhazé C, Aïnouche A, Monnier C, Özkum D, Larher F (2006). Clustering of halophytes from an inland salt marsh in Turkey according to their ability to accumulate sodium and nitrogenous osmolytes. Environ Exp Bot 57:139-153.

Torres C (2007). Contribución al studio de la flora vascular de la comarca de Los Serranos (Valencia). Trabajo de Investigación. Programa de doctorado 610-025 D Botánica y fisiología vegetal. Valencia.

Verbruggen N, Hermans C (2008). Proline accumulation in plants: a review. Amino Acids 35:753-759.

Verheye WH, Boyadgiev TG (1997). Evaluating the land use potential of gypsiferous soils from field pedogenic characteristics. Soil Use Manage 13:97-103.

Wang M, Zheng Q, Shen Q, Guo S (2013). The critical role of potassium in plant stress responses. Int J Mol Sci 14:7370-7390.

Wankhade SD, Sanz A (2013). Chronic mild salinity affects source leaves physiology and productivity parameters of rice plants (Oryza sativa L., cv. Taipei 309). Plant Soil 367:663-672. 